\title{
Characterisation of Rosa Mosqueta seeds: cell wall polysaccharide composition and light microscopy observations
}

\author{
Fernando Dourado, ${ }^{1}$ Pedro Vasco, ${ }^{1,2}$ Francisco M Gama, ${ }^{1}$ Manuel A Coimbra ${ }^{2}$ and \\ Manuel Mota ${ }^{1 *}$ \\ ${ }^{1}$ Centro de Engenharia Biológica—IBQF, Largo do Paço, Universidade do Minho, P-4719 Braga, Portugal \\ ${ }^{2}$ Departamento de Química, Universidade de Aveiro, P-3810-193 Aveiro, Portugal
}

\begin{abstract}
The utilisation of enzymes for the extraction of vegetable oils from seeds has been a topic of growing interest in recent years. Knowledge of the cell wall polysaccharide composition is important to select the enzyme(s) necessary for the most effective degradation of the cell walls. The purpose of the present work is to characterise the seeds of Rosa Mosqueta (Rosa aff rubiginosa) by light microscopy (where several differential staining methods were applied to analyse the seed structure) and by the isolation of cell wall polysaccharide extracts. The mature seed of Rosa Mosqueta has a very thick and structurally complex seed coat comprising heavily lignified tissue. The embryo has two cell layers of remaining endosperm tissue (indicating that this is an exalbuminous seed), two voluminous cotyledons that contain the oil, and bundles of provascular tissues distributed perpendicularly to the transverse axis of the embryo. The major non-cellulosic polysaccharides from the non-lignified tissues are glucuronoxylans and pectic polysaccharides; glucans are also present in small amounts. The major non-cellulosic polysaccharides from the lignified tissues are glucuronoxylans. Concerning the use of enzymes for oil extraction, microscopy and cell wall polysaccharide analysis showed that the use of pectic enzymes followed by a xylanase or a cellulase should be explored.

(C) 2000 Society of Chemical Industry
\end{abstract}

Keywords: Rosa Mosqueta; light microscopy; cell wall polysaccharides; seed structure; staining methods

\section{INTRODUCTION}

The recovery and use of vegetable oils from seeds have played an important role in the manufacture of a large number of industrial products and human food items.

In recent years there has been a growing interest in the oil extracted from the seeds of Rosa Mosqueta. Despite the small amount of oil extracted from these seeds (approximately $8 \%$ according to Malec et $a l^{1}$ ), the annual seed production is roughly 20000 tons, $^{2}$ increasing the economic interest in this product owing to its use for cosmetic and medicinal purposes. ${ }^{1,3,4}$ 'Rosa Mosqueta' is the common name used for at least three species widely distributed in Chile: Rosa aff rubiginosa, the main representative (a good morphological description of this species, both plant and fruit, can be found in Ref 3), Rosa canina and Rosa moschata. ${ }^{3}$ Information about the Rosa species is rather scarce.

The process for extraction of vegetable oils is based on the observation that the oil is found inside the plant cells, linked together with protein and various complex carbohydrate molecules. ${ }^{5}$ The permeability of the cells to oil can be increased by mechanical or thermal conditioning. ${ }^{6}$ A more recent technology involves the utilisation of enzymes to degrade the cell walls. However, the enzyme preparations must have a broad spectrum of activity owing to the complex structure of the cell walls. ${ }^{5}$ In order to define more precisely the type(s) of enzyme(s) to degrade the cell wall polysaccharides, and consequently increase the efficiency of degradation of Rosa Mosqueta cell walls, polysaccharides were extracted and characterised. In a parallel study the seed structure and localisation of the embryo's food reserves were determined by light microscopy.

\section{MATERIALS AND METHODS \\ Plant material}

Rosa Mosqueta seeds were obtained from Chile, with an average length of $5.2 \mathrm{~mm}$, an average diameter of $4.2 \mathrm{~mm}$ and $2 \%$ moisture content. They were stored inside a metallic container at room temperature and analysed within 1 year after harvest.

\section{Optical microscopy}

Sample preparation

The seeds were placed in boiling distilled water for

* Correspondence to: Manuel Mota, Centro de Engenharia Biológica—IBQF, Largo do Paço, Universidade do Minho, P-4719 Braga, Portugal (Received 11 May 2000; accepted 24 May 2000) 
$5 \mathrm{~min}$ in order to inhibit endogenous enzymatic activity and to soften the thick seed coat. The seeds were then washed with distilled water and conserved in aqueous medium for 4 days to further soften the seed coat. Afterwards the extremities of the oval-shaped seeds were cut to allow better penetration of the fixing agents. Sectioned seeds were fixed for $18 \mathrm{~h}$ at $4{ }^{\circ} \mathrm{C}$ with $10 \%$ formalin in phosphate buffer $(0.1 \mathrm{M}, \mathrm{pH} 7.0)$. Fixation was followed by washing with phosphate buffer at $4^{\circ} \mathrm{C}$ for $18 \mathrm{~h}$ with several batches of buffer solution, followed by dehydration in a graded ethanol series $(50,60,70,80,90 \%$ and absolute ethanol) at $4{ }^{\circ} \mathrm{C}$. Each dehydration step lasted for $20 \mathrm{~min}$. The seeds were then transferred to a monomer mixture (two steps, 3 days each, at room temperature) containing 94\% glycol methacrylate, 3\% 2-butoxyethanol, 1.5\% polyethylene glycol 400 (PEG 400), $0.75 \%$ divinylbenzene, $0.75 \%$ methyl methacrylate and $0.72 \mathrm{~g}$ benzoyl peroxide for each $80 \mathrm{ml}$ of monomer mixture (modified from Ref 7). Embedding was carried out in the same mixture without PEG but with $25 \mu \mathrm{l} 2,2$-azobis(2-methylpropionitrile) for each $3 \mathrm{ml}$ of mixture, allowing the polymerisation to occur at room temperature. Sections of $4-6 \mu \mathrm{m}$ were obtained using glass knives and an ultramicrotome model 1401 (Leitz).

\section{Staining}

The sections were examined with the following methods: Safranin and Picro Aniline Blue; PAS (Periodic Acid Shiff's reagent) -Amido Black; ${ }^{8}$ Coomassie Brilliant Blue R250; ${ }^{9}$ Sudan Black ${ }^{10}$ (sections were stained for $30 \mathrm{~min}$; the saturated staining solutions were also made in $70 \%$ propanol). Sections were also stained with Premixed Iron Hematoxylin, Safranin and Fast Green ${ }^{8}$ (results not shown). For some of the stained sections the original mounting medium referred to in $\operatorname{Ref}^{8}$ was Canada balsam. In this work, Entellan was used to prevent colour fading.

\section{Preparation of alcohol-insoluble residue (AIR)}

The seeds $(74.5 \mathrm{~g})$ were frozen in liquid nitrogen and immediately ground in a coffee mill to a final particle size of approximately $0.5 \mathrm{~mm}$ after sieving. The material was then refluxed in $300 \mathrm{ml}$ ethanol for $15 \mathrm{~min}$. The mixture was cooled and filtered through a size 1 sintered glass funnel (P160/ISO 4793, 100$160 \mu \mathrm{m}$ pore size). In order to remove the oil, the residue was treated twice with $300 \mathrm{ml}$ of a chloroform/ methanol $(2: 1 \mathrm{v} / \mathrm{v})$ solution for $30 \mathrm{~min}$. The residue was washed with absolute ethanol and diethyl ether before being placed in an oven at $40^{\circ} \mathrm{C}$ until no weight variation was detected. ${ }^{11}$

\section{Sequential extraction of AIR}

AIR (20 g) was treated with distilled water $(400 \mathrm{ml})$ at $40^{\circ} \mathrm{C}$ for $75 \mathrm{~min}$ (W-1) and sequentially extracted with dimethyl sulphoxide (DMSO, $400 \mathrm{ml}$ ) at $20^{\circ} \mathrm{C}$ for $20 \mathrm{~h}$ (DMSO-1), then washed with distilled water $(5 \times 150 \mathrm{ml})$ to complete removal of DMSO (W-2),
$0.5 \mathrm{M} \mathrm{KOH}(500 \mathrm{ml})$ at $4^{\circ} \mathrm{C}$ for $2 \mathrm{~h}, 1 \mathrm{M} \mathrm{KOH}(500 \mathrm{ml})$ at $4^{\circ} \mathrm{C}$ for $2 \mathrm{~h}, 1 \mathrm{M} \mathrm{KOH}(500 \mathrm{ml})$ at $20^{\circ} \mathrm{C}$ for $2 \mathrm{~h}$ and $4 \mathrm{M} \mathrm{KOH}(500 \mathrm{ml})$ at $20^{\circ} \mathrm{C}$ for $2 \mathrm{~h}$. After each extraction step the mixture was filtered, concentrated under reduced pressure and dialysed for 3 days, with several changes of distilled water. The alkali extracts were previously acidified to $\mathrm{pH} 5.0$ with glacial acetic acid, concentrated and dialysed. After dialysis, all the extracts were centrifuged and the precipitates (ppt) were separated from the soluble material (supernatant (sn)). Finally, they were concentrated and freezedried. For convenience of presentation and discussion of the results, the $\mathrm{KOH}$ extracts were combined in fractions $\mathrm{KOH}-1$ sn and $\mathrm{KOH}-1$ ppt. The residue obtained (CR-1) was washed with distilled water $(250 \mathrm{ml})$, neutralised, dialysed and freeze-dried; the supernatant was collected separately (sn-CR-1). To prevent $\beta$-elimination, peeling reactions and alkaline oxidation of the polysaccharides, the $\mathrm{KOH}$ extractions were carried out under an inert atmosphere (Ar) with $\mathrm{O}_{2}$-free solutions containing $20 \mathrm{~mm} \mathrm{NaBH}_{4}$. $\mathrm{KOH}$ solutions were prepared according to the following procedure: the distilled water used for the preparation of the solutions was boiled for $20 \mathrm{~min}$ and allowed to cool under Ar; $\mathrm{KOH}$ (for each required concentration) and $\mathrm{NaBH}_{4}$ were then added and dissolved.

\section{Mild chlorite treatment}

CR-1 (12.5 g) was treated with 11 of $30 \mathrm{mg} \mathrm{l}^{-1} \mathrm{NaClO}_{2}$ and $1.2 \mathrm{ml}^{-1}$ glacial acetic acid at $70^{\circ} \mathrm{C}$ for $4 \mathrm{~h}$. During the reaction, $30 \mathrm{mg}^{-1} \mathrm{NaClO}_{2}$ and $1.2 \mathrm{ml}^{-1}$ glacial acetic acid were added every hour. The chlorite-soluble material was concentrated and dialysed. The supernatant (Ch-1 sn) was removed from the precipitate (Ch-1 ppt) and they were both freezedried. The residue was extracted with DMSO $(600 \mathrm{ml})$ at $20^{\circ} \mathrm{C}$ for $90 \mathrm{~h}$ to give DMSO-2. To completely remove the DMSO, the residue was washed with distilled water $(6 \times 150 \mathrm{ml})$, which was collected for analysis (W-3).

\section{Delignification treatment}

The washed residue was placed in 11 of reaction mixture containing $3 \mathrm{gl}^{-1} \mathrm{NaClO}_{2}$ and $1.2 \mathrm{ml}^{-1}$ glacial acetic acid at $70^{\circ} \mathrm{C}$ for $4 \mathrm{~h}$, according to the procedure of Jermyn and Isherwood. ${ }^{12}$ During the reaction, $3 \mathrm{~g} \mathrm{l}^{-1} \mathrm{NaClO}_{2}$ and $1.2 \mathrm{ml}^{-1}$ glacial acetic acid were added every hour. The obtained yellow solution was filtered and the residue was washed thoroughly with distilled water $(6 \times 150 \mathrm{ml})$. All filtrates were combined and flushed with $\mathrm{N}_{2}$ until a pale yellow solution was obtained, indicating that the dissolved chlorine dioxide was removed. The solution was then concentrated in a rotary evaporator at $40^{\circ} \mathrm{C}$, dialysed and freeze-dried (Ch-2). The residue obtained after the chlorite treatment is usually referred to as holocellulose. ${ }^{13}$ Chlorine dioxide can inhibit the free radical chain reaction between chlorine and polysaccharides during delignification by acting as free radical scavenger. It acts without affecting the 
chlorination of lignin, which is not a free radical reaction. Chorine dioxide by itself reacts only very slowly with polysaccharides. ${ }^{14,15}$

\section{Sequential extraction of holocellulose}

The holocellulose was sequentially extracted with DMSO $\left(600 \mathrm{ml}, 20^{\circ} \mathrm{C}, 20 \mathrm{~h}\right)(\mathrm{DMSO}-3)$, then washed with distilled water $(5 \times 150 \mathrm{ml})$ to complete removal of DMSO (W-4), $0.5 \mathrm{M} \mathrm{KOH}+20 \mathrm{mM} \mathrm{NaBH}_{4}$ $\left(500 \mathrm{ml}, 20^{\circ} \mathrm{C}, 2 \mathrm{~h}\right), 1 \mathrm{M} \mathrm{KOH}+20 \mathrm{~mm} \mathrm{NaBH}_{4}$ $\left(500 \mathrm{ml}, 20^{\circ} \mathrm{C}, 2 \mathrm{~h}\right)$ and $4 \mathrm{M} \mathrm{KOH}+20 \mathrm{mM} \mathrm{NaBH}_{4}$ $\left(500 \mathrm{ml}, 20^{\circ} \mathrm{C}, 2 \mathrm{~h}\right)$. The extracts were processed using the same procedure as described for the AIR sequential extraction, and the aqueous suspension containing the final residue was neutralised, dialysed and, before freeze-drying, the supernatant solution (sn-CR-2) was separated from the residue (CR-2) by centrifugation.

\section{Carbohydrate analysis}

Neutral sugars were released by Saeman hydrolysis ${ }^{16}$ and analysed as their alditol acetates by gas-liquid chromatography ${ }^{17,18}$ in a Carlo Erba GC 6000 series 2 with an FID detector and DB 225 column. Hexuronic acids (HexA) were determined colorimetrically by a modification of the method of Blumenkrantz and Asboe-Hansen ${ }^{19}$ according to Coimbra et al. ${ }^{11}$

\section{RESULTS AND DISCUSSION \\ Optical microscopy}

Plate 1 shows the light micrographs of transverse sections of Rosa Mosqueta mature embryo. It is possible to observe the different parts of the mature embryo stained by the PAS-Amido Black method (Plates 1A, 1C, 1E and 1G), where proteins stain blue and carbohydrates stain red (from personal experience we can affirm that the intensity of the colour varies from light straw to red according to the polysaccharide composition). Coomassie Blue, a stain for proteins (which stain blue), was also used (Plates $1 \mathrm{D}, 1 \mathrm{~F}$ and $1 \mathrm{H})$. The transverse section (Plate $1 \mathrm{~A}$ ) shows that this angiospermic seed has two voluminous cotyledons. These cells (Plates $1 \mathrm{E}$ and $1 \mathrm{~F}$ ) have a quite homogeneous internal organisation, with big protein bodies, or aleurone grains, ${ }^{20}$ as food reserves. Some of these protein bodies are structurally simple and apparently consist only of a proteinaceous matrix, whereas others have inclusions (in) such as globoid crystals, protein crystalloids or calcium oxalate crystals. Mineral nutrient reserves are usually concentrated as globoid crystals and are a constituent of phytin. ${ }^{21}$

The provascular tissue (Plates 1C and 1D) is oriented in small bundles perpendicular to the transverse embryonic axis (Plate 1A). The protein bodies of these cells are the smallest in size and number, and apparently the simplest in terms of structure, when compared to those of the cotyledons and endosperm (Plates $1 \mathrm{G}$ and $1 \mathrm{H}$ ), indicating that these cells have fewer nutrient (protein) reserves. Also, the higher density of the cytoplasm (as compared to the cotyledon and endosperm cells) suggests that the provascular cells have a higher number of cellular organelles (Plate 1D).

The endosperm tissue (en) can be observed in Plates $1 \mathrm{G}$ and $1 \mathrm{H}$. These cells are smaller, more elongated and have a higher number of protein bodies. These bodies are smaller than those of the cotyledon cells but appear to have a higher number of inclusions. The endosperm tissue is restricted to two layers of cells that surround the mature embryo (Plates $1 \mathrm{~A}, 1 \mathrm{G}$ and $1 \mathrm{H}$ ). This tissue is an important food reserve for the young developing embryo, but in many dicotyledonous seeds the development of the embryo prior to seed germination destroys all or most of the endosperm. Seeds of this type are designated as exalbuminous and, at maturity, consist of a large embryo enclosed within the seed coat. $^{22}$

The embryo's epidermis (ep), derived from its protoderm during maturation, is shown in Plate $1 \mathrm{H}$.

Plate 1B shows the cotyledon cells stained with Sudan Black, where lipids stain black. Lipids are present in both the embryo and endosperm. The cytoplasm of these cells is completely stained, suggesting that small lipid droplets, also known as oleosomes and spherosomes, ${ }^{20}$ are dispersed throughout the cytoplasm. However, in our experiments we verified that the plastic embedding medium (GMA) was also stained, thus rendering the above observation inconclusive. Moreover, as mentioned in the Introduction, data from Ref 1 show that the oil content of these seeds is approximately $8 \%$, which is not consistent with the staining results shown here. The protein bodies were also stained. Since the amount of protein content of the seeds, following complete removal of the oil, is nearly $10 \%,{ }^{1}$ it is possible that the protein bodies consist of a complex matrix composed of lipids and proteins.

Plate 2 shows the light micrographs of transverse sections of Rosa Mosqueta seed coat. An overall observation of the cell walls of the seed coat (Plates 2I2P) shows that they are relatively thick when compared to the different embryonic structures (Plates $1 \mathrm{~A}-1 \mathrm{H})$. This suggests that the reserve carbohydrates in this seed are rather scarce. Using the Safranin and Picro Aniline Blue method (where cellulose stains blue and lignin stains red), the embryo and endosperm tissue cell walls stained blue (data not shown), indicating that it is probable that they are mainly composed of cellulose.

Plate 2I shows an overall view of the very thick embryonic seed coat (or testa), which made GMA sections very difficult to obtain for this type of seed. In this micrograph it is possible to distinguish the outer tegument or integument (oi) from the inner tegument (ii). However, no visible separation exists between these two structures. Probably this is the result of a degeneration or compression of the separation layer, as both integuments achieved their maximum thickness when mature. A proper ontogenic study would clarify this hypothesis and would also clarify the development 

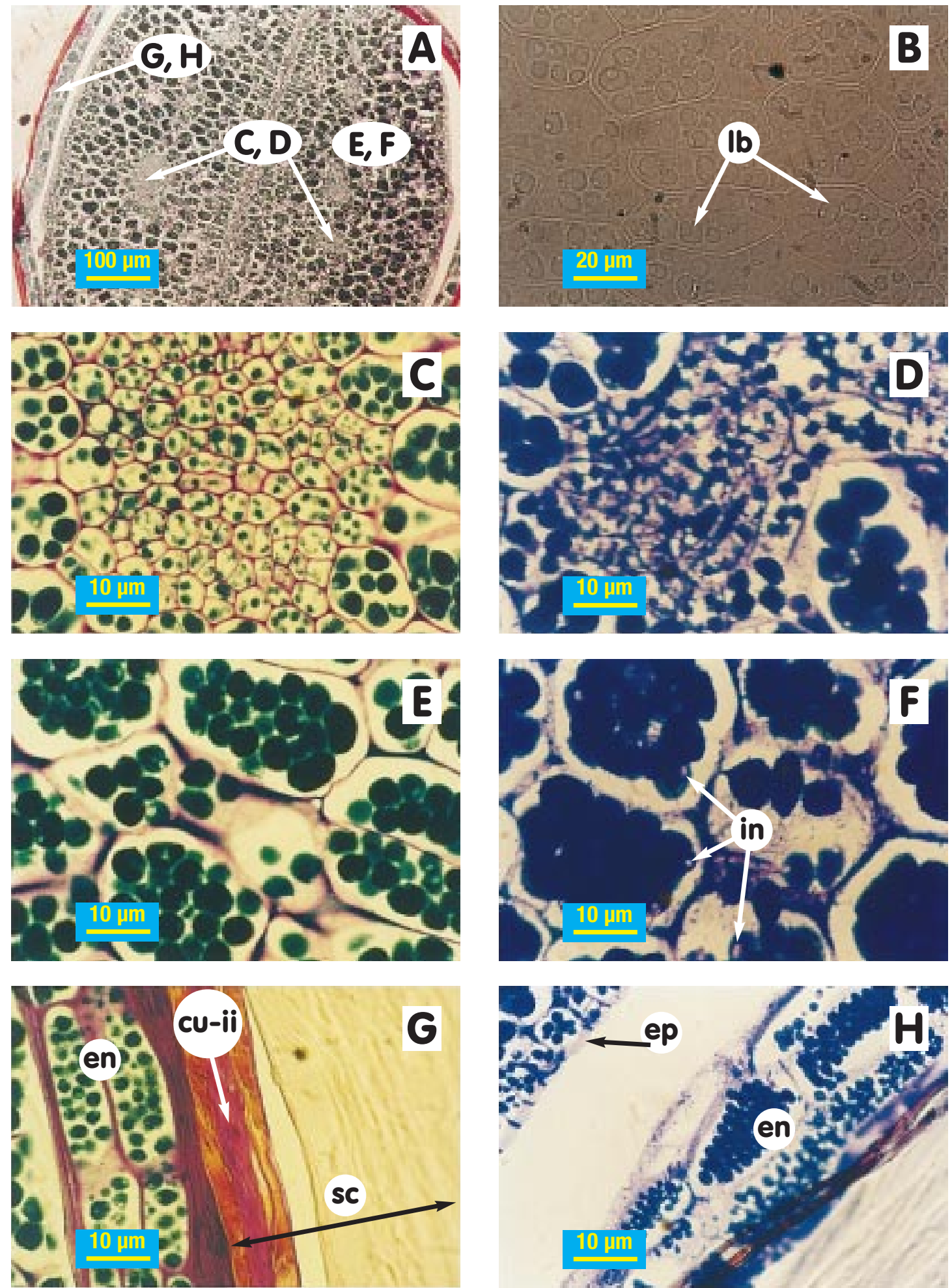

Plate 1. Light micrographs of transverse sections from the mature embryo of $R$ Mosqueta

A: Mature embryo, 100 X; C, D: Provascular tissue, 1000 X; B: Cotyledon cells, 630 X; E, F: Cotyledon cells, $1000 \mathrm{X} ; \mathrm{G}, \mathbf{H}$ : Endosperm (en), $1000 \mathrm{X}$

Ib - Lipid bodies; en - endosperm; ep - epidermis; sc - seed coat; in - inclusions; cu-ii - cuticle from the inner integument

Staining: A, C, E, G: PAS - Amido Black; D, F, H: Coomassie Blue; B: Sudan Black 

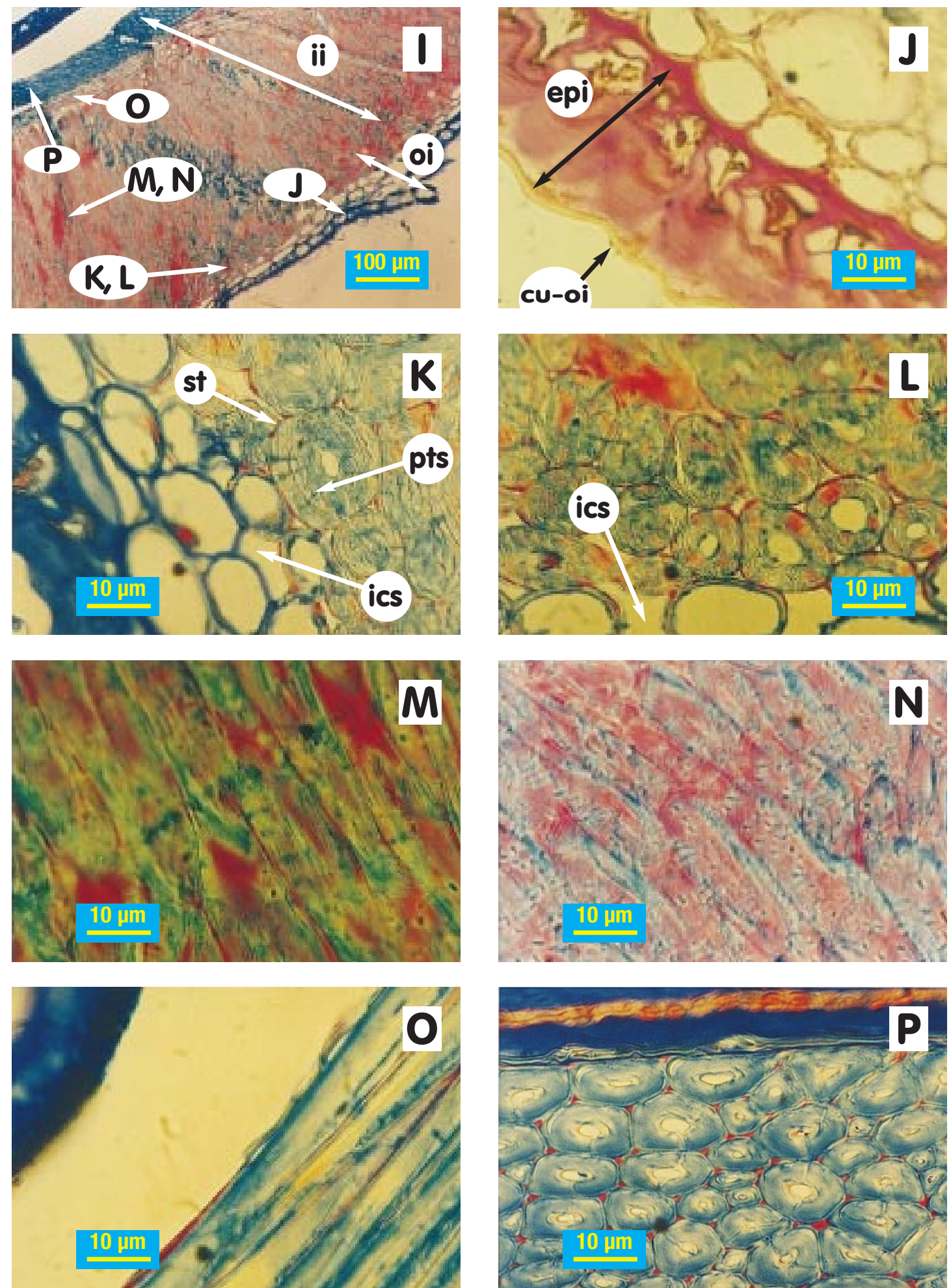

Plate 2. Light micrographs of transverse sections from the seed coat of $R$ Mosqueta seeds

I: Overview of testa (seed coat), $100 \mathrm{X}$, J: Epidermis (epi) of the seed coat; K, L: Stone cells (st); some cells contain conspicuous simple with pits (pts) with many branches, $1000 \mathrm{X} ; \mathbf{M}, \mathbf{N}$ : Sclerenchyma tissue, $1000 \mathrm{X}$;

O: zone of very long fibers, disposed longitudinally, $1000 \mathrm{X}$; P: Zone of fiber disposed transversally, $1000 \mathrm{X}$

oi - outer integument; ii - inner integument; cu-oi - cuticle covering the epidermis (epi); cu-ii - cuticle from the inner integument; ics - intercellular spaces

Staining: J: Pas - Amido Black; all others: Safranin and Picro Aniline Blue 
of the cuticle of the inner integument (cu-ii) (Plates $1 \mathrm{G}$ and $2 \mathrm{P})$.

The epidermis (epi) (Plate 2J) is the outermost layer of cells surrounding the outer seed coat. In this type of seed, this tissue consists of a monolayer of cells covered by a protective tissue named the cuticle (cuoi) (Plate 2J). As shown by the Safranin and Picro Aniline Blue stains (cellulose stains blue and lignin stains red), the epidermis cell wall is non-lignified, probably mainly composed of cellulose.

There is a double (and, in some regions, triple) layer of cells next to the epidermis, displaying a small degree of thickening (Plates 2J and 2K). These cells exhibit a small degree of orientation and packing, and intercellular spaces (ics) can be observed (Plates $2 \mathrm{~K}$ and 2L). Some deposition of lignin is evident. These figures also show stone cells or sclereids (st). The secondary walls of these cells are very thick and contain conspicuous simple pits (pts) with many branches. This tissue is heavily lignified.

An observation of the morphological structure of the seed coat closer to the embryo shows a thick layer of sclerenchyma cells (Plates $2 \mathrm{M}$ and $2 \mathrm{~N}$ ) that also stained strongly for lignin. These cells are tightly packed. A zone of fibres is evident in Plates $2 \mathrm{O}$ and $2 \mathrm{P}$. The outer layer (Plate 2O) of this cellulosic tissue shows that these fibres are very long and also well packed. In the inner layer, close to the embryo's endosperm (Plate 2P), the same fibres are disposed perpendicularly.

The complex structure of this seed coat provides high protection against adverse environmental conditions and diseases. For the sake of clarity, a schematic representation of the embryo's seed coat is shown in Fig 1.

\section{AIR preparation and sequential extraction prior to chlorite treatment}

The strategy used for the sequential extraction of cell wall polysaccharides was defined to remove first those polymers present in the embryo endosperm and then, after the delignification step, those polymers held in the cell walls by lignin.

The preparation of AIR retained $85 \%$ of the initial seed weight. AIR is rich in xylose and glucose residues, and the total AIR carbohydrate content accounted for only $52 \%$ of its dry weight (Table 1). CR-1, the residue obtained after the sequential extraction of AIR with water, DMSO and $\mathrm{KOH}$ solutions, was richer in carbohydrates than AIR (63\%). This residue contains $53 \mathrm{~mol} \% \mathrm{Glc}$ and $37 \mathrm{~mol} \% \mathrm{Xyl}$. The high amount of $\mathrm{Xyl}$ in CR-1 indicates that the reagents used were not efficient for the extraction of a significant amount of Rosa Mosqueta hemicellulosic material. In this first extraction sequence the majority of the material was solubilised with $\mathrm{KOH}$ solutions ( $\mathrm{KOH}-1)$, and $45 \%$ of this extract became insoluble upon neutralisation. These two fractions were very rich in $\mathrm{Xyl}$ and also contain HexA. The absence of significant amounts of sugars other than $\mathrm{Xyl}$ and HexA suggests that this extract contains mainly glucuronoxylan, a polymer that occurs in the cell walls of lignified dicotyledonous plants. ${ }^{23-25}$ The ratio Xyl/HexA gives the mean degree of branching of the glucuronoxylans. The polymers present in $\mathrm{KOH}-1 \mathrm{ppt}$ had a ratio of $8.8 \mathrm{Xyl}$ residues to 1 HexA residue; KOH-1 sn had a proportion of 4.3:1. The higher solubility of the more branched glucuronoxylans in water, after dialysis, was in accordance with the observations reported previously for olive seed hull glucuronoxylans. ${ }^{15}$ In order to further solubilise the hemicellulosic material from Rosa
Figure 1. Schematic representation of the Rosa Mosqueta seed coat.

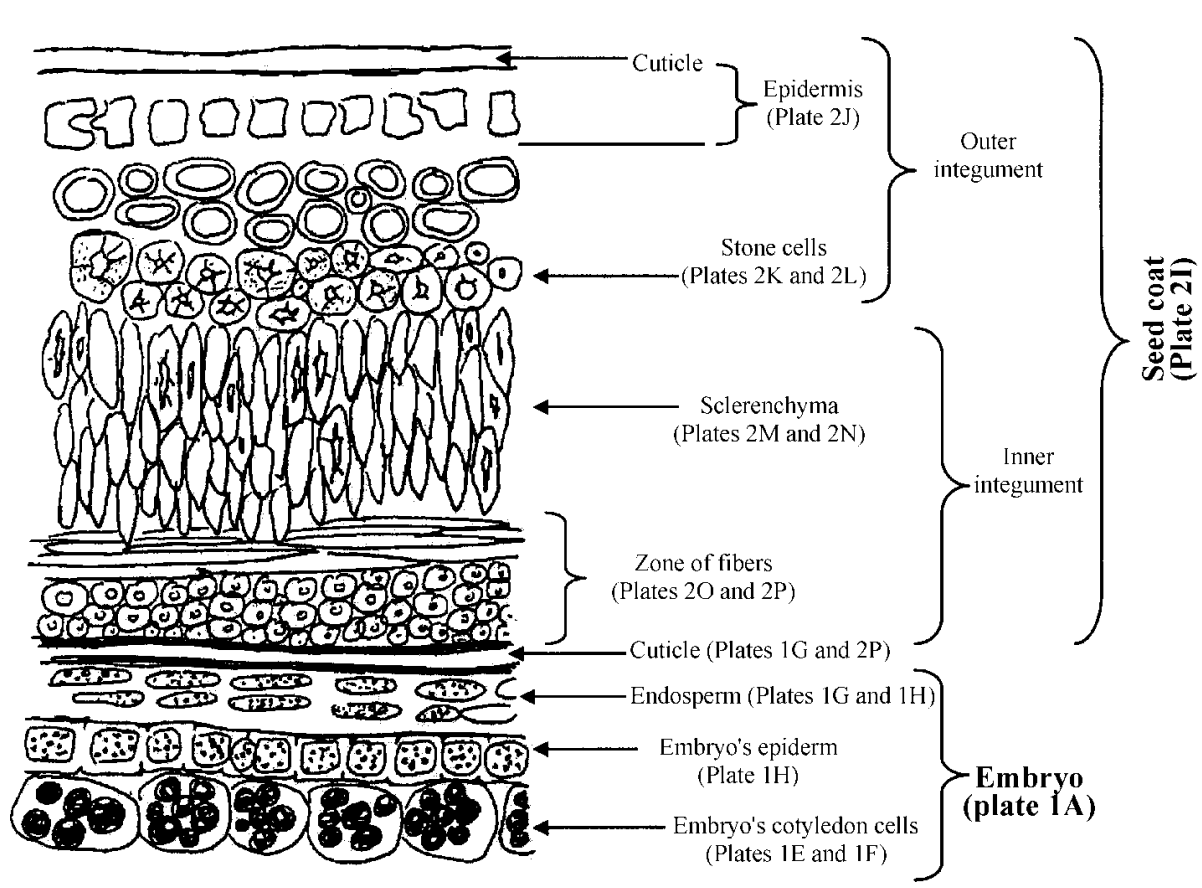


Table 1. Sugars composition of the cell wall fractions from Rosa Mosqueta seeds obtained by sequential extractions

\begin{tabular}{|c|c|c|c|c|c|c|c|c|c|c|}
\hline \multirow[b]{2}{*}{ Fraction } & \multirow[b]{2}{*}{ Recovery (\% w/w) } & \multicolumn{8}{|c|}{ Cell wall sugars (mol\%) } & \multirow[b]{2}{*}{ Total sugars ${ }^{\mathrm{a}}\left(\mathrm{mgg}^{-1}\right.$} \\
\hline & & Rha & Fuc & Ara & $x y l$ & Man & $\mathrm{Gal}$ & Glc & HexA & \\
\hline AIR & 85.33 & $\operatorname{tr}$ & & 2 & 43 & $\operatorname{tr}$ & 1 & 40 & 14 & 524 \\
\hline $\mathrm{H}_{2} \mathrm{O} 40^{\circ} \mathrm{C}(\mathrm{W}-1)$ & $0.62^{b}$ & 7 & & 27 & 4 & $\operatorname{tr}$ & 12 & 9 & 41 & 324 \\
\hline DMSO-1 & $0.87^{\mathrm{b}}$ & 6 & & 10 & 59 & 3 & 2 & 20 & $\operatorname{tr}$ & 127 \\
\hline W-2 & $0.37^{\mathrm{b}}$ & 6 & & 19 & 20 & 2 & 8 & 22 & 23 & 163 \\
\hline \multicolumn{11}{|l|}{$\mathrm{KOH}-1$} \\
\hline$s n^{d}$ & $3.27^{b}$ & 5 & & 4 & 73 & & 1 & $\operatorname{tr}$ & 17 & 266 \\
\hline $\mathrm{ppt}^{\mathrm{d}}$ & $2.72^{\mathrm{b}}$ & $\operatorname{tr}$ & & 1 & 88 & & & 1 & 10 & 546 \\
\hline \multicolumn{11}{|l|}{ Residue } \\
\hline sn-CR-1 & $0.53^{b}$ & 3 & & 10 & 39 & & 3 & 18 & 27 & 206 \\
\hline CR-1 & $62.62^{b}$ & $\operatorname{tr}$ & & 2 & 37 & $\operatorname{tr}$ & $\operatorname{tr}$ & 53 & 8 & 627 \\
\hline \multicolumn{11}{|l|}{ Ch-1 } \\
\hline sn & $1.27^{\mathrm{C}}$ & & & 15 & 20 & $\operatorname{tr}$ & 5 & $\operatorname{tr}$ & 60 & 857 \\
\hline ppt & $0.72^{\mathrm{C}}$ & $\operatorname{tr}$ & & 1 & 15 & $\operatorname{tr}$ & $\operatorname{tr}$ & 16 & 68 & 920 \\
\hline \multicolumn{11}{|l|}{ DMSO-2 } \\
\hline sn & $1.30^{\mathrm{C}}$ & 1 & $\operatorname{tr}$ & $\operatorname{tr}$ & 78 & & 1 & 2 & 18 & 568 \\
\hline ppt & $1.16^{\mathrm{C}}$ & $\operatorname{tr}$ & 2 & tr & 51 & $\operatorname{tr}$ & 1 & 33 & 13 & 350 \\
\hline \multicolumn{11}{|l|}{ W-3 } \\
\hline sn & $0.23^{c}$ & $\operatorname{tr}$ & $\operatorname{tr}$ & $\operatorname{tr}$ & 69 & $\operatorname{tr}$ & 1 & 10 & 20 & 327 \\
\hline ppt & $0.04^{c}$ & $\operatorname{tr}$ & 1 & tr & 30 & 1 & 1 & 54 & 13 & 374 \\
\hline \multicolumn{11}{|l|}{ Ch-2 } \\
\hline sn & $6.39^{c}$ & 8 & 8 & 6 & 49 & & 6 & 1 & 22 & 149 \\
\hline ppt & $0.20^{c}$ & $\operatorname{tr}$ & & $\operatorname{tr}$ & 17 & $\operatorname{tr}$ & 1 & 37 & 45 & 435 \\
\hline \multicolumn{11}{|l|}{ Holocellulose } \\
\hline \multicolumn{11}{|l|}{ DMSO-3 } \\
\hline sn & $3.62^{c}$ & $\operatorname{tr}$ & 2 & tr & 81 & $\operatorname{tr}$ & 1 & $\operatorname{tr}$ & 16 & 488 \\
\hline ppt & $0.27^{c}$ & 4 & $\operatorname{tr}$ & $\operatorname{tr}$ & 74 & 1 & $\operatorname{tr}$ & 9 & 12 & 519 \\
\hline \multicolumn{11}{|l|}{$W-4$} \\
\hline sn & $0.49^{c}$ & $\operatorname{tr}$ & & tr & 80 & $\operatorname{tr}$ & 1 & 4 & 15 & 396 \\
\hline ppt & $0.06^{c}$ & $\operatorname{tr}$ & 1 & tr & 25 & 1 & 1 & 62 & 10 & 565 \\
\hline \multicolumn{11}{|l|}{$0.5 \mathrm{M} \mathrm{KOH}$} \\
\hline sn & $6.02^{c}$ & 1 & & 2 & 67 & 2 & 2 & $\operatorname{tr}$ & 26 & 484 \\
\hline ppt & $1.61^{\mathrm{c}}$ & 1 & & 2 & 81 & & & & 16 & 799 \\
\hline \multicolumn{11}{|l|}{$1 \mathrm{M} \mathrm{KOH}$} \\
\hline sn & $2.14^{c}$ & 1 & 1 & 1 & 78 & $\operatorname{tr}$ & 2 & 1 & 16 & 852 \\
\hline ppt & $6.79^{c}$ & $\operatorname{tr}$ & & tr & 86 & & & 1 & 13 & 877 \\
\hline \multicolumn{11}{|l|}{$4 \mathrm{M} \mathrm{KOH}$} \\
\hline sn & $3.41^{c}$ & $\operatorname{tr}$ & 1 & tr & 90 & & 1 & 1 & 7 & 288 \\
\hline ppt & $0.47^{c}$ & 1 & $\operatorname{tr}$ & 1 & 83 & $\operatorname{tr}$ & & 2 & 13 & 796 \\
\hline \multicolumn{11}{|c|}{ Cellulosic residue 2} \\
\hline sn-CR-2 & $0.68^{\mathrm{C}}$ & 10 & & 2 & 5 & & 1 & 52 & 30 & 432 \\
\hline CR-2 & $30.69^{c}$ & 2 & $\operatorname{tr}$ & tr & 6 & 1 & tr & 76 & 15 & 629 \\
\hline
\end{tabular}

HexA, hexuronic acid; sn, supernatant on dialysis; ppt, precipitate on dialysis; tr, trace; blank spaces, not detected

a Values are expressed as $\mathrm{mg}$ anhydrosugar $\mathrm{g}^{-1}$.

b Values are expressed as\% AIR.

${ }^{c}$ Values are expressed as\% CR-1.

${ }^{\mathrm{d}}$ Values are a weighted average of $\mathrm{KOH}$ sn and ppt extracts in the first sequential extraction.

Mosqueta cell walls using the less aggressive possible agents, a mild chlorite treatment at $70^{\circ} \mathrm{C}$ was assayed.

\section{Mild delignification}

Mild chlorite treatment provided two fractions very rich in sugars. The fraction that remained soluble after dialysis (Ch-1 sn) represented $1.3 \%$ of CR-1. It was rich in HexA, Xyl, Ara and Gal, a sugar composition characteristic of pectic polysaccharides (HexA, Ara and Gal) and glucuronoxylans. The fraction that precipitated was rich in HexA, Glc and Xyl, which are characteristic of unbranched pectic polysaccharides, xylans and, possibly, glucans. The FT-IR spectra of these fractions ${ }^{26,27}$ confirmed the presence of pectic polysaccharides (data not shown). The occurrence of pectic substances in highly lignified tissues was previously reported by Coimbra et $a l^{15}$ in olive seed hull, and recently it was also shown to occur in cork middle lamella. ${ }^{28}$

DMSO is known to be a good solvent for xylans. ${ }^{13}$ DMSO-2 soluble material accounts for $2.5 \%$ of CR-1 and mainly consists of glucuronoxylans, although the 
material insoluble in water also contains some glucans. The water used to wash out DMSO (W-3), although in small amounts, contained polymers rich in Glc that tended to become insoluble upon complete removal of DMSO by dialysis.

Because the amount of xylans solubilised in DMSO2 was not significant when compared with the amount of Xyl of CR-1, a delignification treatment was performed.

\section{Delignification treatment}

The delignification of the residue obtained after DMSO-2 extraction gave the fraction $\mathrm{Ch}-2$, which accounted for $6.6 \%$ of CR-1. The polymeric material present in this extract is composed mainly of degraded lignin (as suggested by the strong UV absorptiondata not shown), since the total sugars accounted for only $16 \%$ of this fraction. The fraction that remained soluble after dialysis is rich in $\mathrm{Xyl}$ and contains significant amounts of $\operatorname{HexA}$; the insoluble fraction is richer in HexA and contains Glc and Xyl. These polymers are probably low-molecular-weight xylan and pectic polysaccharides, as reported to occur in pine $^{29}$ and olive ${ }^{15}$ seed hull.

\section{Sequential extraction of delignified residue (holocellulose)}

The DMSO treatment of holocellulose (DMSO-3) extracted $3.9 \%$ of the material. This extract is very rich in glucuronoxylans. The analysis of the DMSO-3 washing water (W-4) showed the presence of a glucan that could be separated from xylans by centrifugation. This glucan, although in small amounts, tends to appear in the majority of aqueous or DMSO extracts.

$\mathrm{KOH}$ extracts accounted for $20.4 \%$ of CR-1. The polysaccharides present in these extracts were glucuronoxylans. The precipitates are very rich in sugars and present $\mathrm{Xyl} /$ HexA ratios of $5.1: 1,6.6: 1$ and $6.4: 1$ respectively for the $0.5,1$ and $4 \mathrm{M} \mathrm{KOH}$ extractions. The glucuronoxylans present in the supernatants tend to have lower ratios (except for $4 \mathrm{M} \mathrm{KOH} \mathrm{sn).} \mathrm{The}$ occurrence of this type of polymer was confirmed by the FT-IR spectra. ${ }^{26,27}$ The small amount of pectic material that was still associated with CR-2 residue was released upon neutralisation. CR-2 was very rich in sugars and is mainly composed of Glc (from cellulose), although small amounts of HexA and Xyl are still present.

The amount of material other than polysaccharides (lignin, other phenolic compounds, protein) present in AIR is $47.6 \%$. This result is comparable to the amount of sugars obtained by the sum of all extracts in relation to the material extracted $(44.2 \%)$. As observed from the microscopic analysis, this material is mainly deposited in the embryo's seed coat. The extraction of polysaccharides from the seed coat of Rosa Mosqueta was only possible after the delignification treatment. Although the types of polymers present before and after the delignification treatment were similar, the sugar composition obtained showed that the non-lignified tissues are richer in pectic polysaccharides and the seed coat is richer in glucuronoxylans. Using the results of the yields and sugar composition shown in Table 1, it can be estimated that Rosa Mosqueta cell wall polysaccharides comprise mainly glucuronoxylans $(47 \%)$, cellulose $(34 \%)$, pectic polysaccharides (17\%) and non-cellulosic glucans (2\%). Pectic polysaccharides may play an important role in the maintenance of the tissue and cell wall integrity. Rocha $e t a l^{28}$ reported that a pectinase treatment of cork cubes containing $1.5 \%$ pectic polysaccharides was responsible for the occurrence of cellular separation and tissue collapse. To increase the extraction of oil from Rosa Mosqueta seeds, its polysaccharide composition allows us to suggest that the pectinase should be used prior to the use of xylanases and/or cellulases.

\section{CONCLUSION}

The mature seed of Rosa Mosqueta has a very thick and structurally complex seed coat with heavily lignified tissues. The embryo has two layers of remaining endosperm tissue (indicating that this is an exalbuminous seed), two voluminous cotyledons that contain the oil, and bundles of provascular tissues distributed perpendicularly to the transverse axis of the embryo.

The extraction of the majority of the polysaccharides from the cell walls of the seeds of Rosa Mosqueta is greatly improved after a delignification treatment. However, $24 \%$ of the material was extracted before delignification. The major non-cellulosic polysaccharides present in the extracts obtained before delignification are pectic polysaccharides, glucuronoxylans and traces of a glucan-type polysaccharide soluble in DMSO but insoluble in water. These polymers seem to arise from the non-lignified tissues of the embryo endosperm. The major non-cellulosic polysaccharides obtained from the lignified tissues are glucuronoxylans, extracted mainly with DMSO and $\mathrm{KOH}$ solutions. This type of polymer seem to arise from the lignified tissues of the seed coat.

Concerning the use of enzymes for oil extraction from the embryo endosperm, microscopy and cell wall polysaccharide analysis showed that the use of pectic enzymes followed by a xylanase or even a cellulase should be explored.

\section{ACKNOWLEDGEMENTS}

This work was partially funded by the European Union (EU Contract INCO-DC: 96-2205). The authors thank Dr Clara Cramez and Dr Jovita Oliveira (Departamento de Engenharia Polímeros, Universidade do Minho, Guimarães) for their help in the sectioning of the GMA, and Dr Rubim A Silva (Departamento de Botânica, Faculdade de Ciências, Porto) for his help in the preparation of the GMA mixture. We are also grateful to Alexandra Nunes and 
Dr António Barros (Departamento de Química, Universidade de Aveiro) for the FT-IR experiments and data analyses.

\section{REFERENCES}

1 Malec LS, Civeira ME and Vigo MS, Semilla de Rosa rubiginosa L. ('Rosa Mosqueta'). Composicion química del aceite crudo de extraccion y de la harina residual. An Asoc Quím Argent 81:445-450 (1993).

2 Rodriguez A, Soto G and Valladares J, Caracterización del aceite crudo de semilla de Mosqueta (Rosa aff. rubiginosa L.). Grasas y Aceites 1:20-22 (1987).

3 Sudzuki FH, Cultivo de Frutales Menores. Editorial Universitaria, Santiago, pp 167-174 (1985).

4 Badolato ESG, Aued-Pimentel S and Tavares M, Óleo natural de Rosa Mosqueta e cosméticos contendo esse óleo: verificação de sua qualidade por cromatografia em fase gasosa. Trabalhos Técnicos/Aerosol E Cosméticos 14:42-47 (1993).

5 Christensen FM, Extraction by aqueous enzymatic processes. INFORM 2:984-987 (1991).

6 Domínguez H, Núñez MJ and Lema JM, Aqueous processing of sunflower kernels with enzymatic technology. Food Chem 53:427-434 (1995).

7 Almeida da Silva RM, Caldas FB and Rosselló J, The taxonomic status of Scilla beirana Samp. (Hyacinthaceae). An Fard Bot Madrid 56:253-260 (1998).

8 Clark G, Staining Procedures, 4th edn, Williams and Wilkins, Baltimore, MD, pp 317, 323, 325-327 (1981).

9 Gahan PB, Plant Histochemistry and Cytochemistry, an Introduction, 1st edn, Academic Press, London, pp 190, 204 (1984).

10 Bancroft JD and Stevens A, Theory and Practice of Histological Techniques. Churchill Livingstone, New York, p 220 (1996).

11 Coimbra MA, Delgadillo I, Waldron KW and Selvendran RR, Isolation and analysis of cell polymers from olive pulp, in Modern Methods of Plant Analysis, Vol 17, Ed by Linskens HF and Jackson JF, Springer, Berlin, pp 18-44 (1996).

12 Jermyn MA and Isherwood FA, Changes in the cell wall of the pear during ripening. Biochem f 64:123-132 (1956).

13 Selvendran RR and O'Neill MA, Isolation and analysis of cell walls from plant material, in Methods of Biochemical Analysis, Vol 32, Ed by Glick D, Wiley, New York, pp 25-153 (1987).

14 Sjöstrom E, Wood Chemistry: Fundamentals and Applications. Academic Press, London (1981).

15 Coimbra MA, Waldron KW and Selvendran RR, Isolation and characterisation of cell wall polymers from the heavily lignified tissues of olive (Olea europaea) seed hull. Carbohydr Polym 27:285-294 (1995).

16 Selvendran RR, March JF and Ring SG, Determination of aldoses and uronic acid content of vegetable fiber. Anal Biochem 96:282-292 (1979).

17 Blakeney AB, Harris PJ, Henry RJ and Stone BA, A simple and rapid preparation of alditol acetates for monosaccharide analysis. Carbohydr Res 113:291-299 (1983).

18 Harris PJ, Blakeney AB, Henry RJ and Stone BA, Gas chromatographic determination of the monosaccharide composition of plant cell wall preparations. I Assoc Off Anal Chem 71:272-275 (1988).

19 Blumenkrantz $\mathrm{N}$ and Asboe-Hansen G, New method for quantitative determination of uronic acids. Anal Biochem 54:484-489 (1973).

20 Rosenthal A, Pyle DL and Niranjan K, Aqueous and enzymatic extraction processes for edible oil extraction. Enzyme Microb Technol 19:402-420 (1996).

21 Bewley D and Black M, Seeds: Physiology of Development and Germination, 2nd edn, Plenum, New York, pp 21-25 (1986).

22 Foster AS and Gifford Jr EM, Comparative Morphology of Vascular Plants, 2nd edn, WH Freeman, San Francisco, CA, p 722 (1974).

23 Aspinall GO, Chemistry of cell wall polysaccharides, in The Biochemistry of Plants, Vol 3, Ed by Preiss J, Academic Press, San Diego, CA, pp 473-500 (1980).

24 Bacic A, Harris PJ and Stone BA, Structure and function of plant cell walls, in The Biochemistry of Plants, Vol 14, Ed by Preiss J, Academic Press, San Diego, CA, pp 297-371 (1988).

25 Reid JSG, Carbohydrate metabolism: structural carbohydrates, in Plant Biochemistry, Ed by Dey PM and Harborne JB, Academic Press, London, pp 205-236 (1997).

26 Coimbra MA, Barros A, Barros M, Rutledge DN and Delgadillo I, Multivariate analysis of uronic acid and neutral sugars in whole pectic samples by FT-IR spectroscopy. Carbohydr Polym 37:241-248 (1998).

27 Coimbra MA, Barros A, Rutledge DN and Delgadillo I, FT-IR spectroscopy as a tool for the analysis of olive pulp cell wall polysaccharide extracts. Carbohydr Res 317:145-154 (1999).

28 Rocha SM, Coimbra MA and Delgadillo I, Demonstration of pectic polysaccharides in cork cell wall from Quercus suber L. $\mathcal{F}$ Agric Food Chem 48(6):2003-2007 (2000).

29 Minor JL, Location of lignin-bonded pectic polysaccharides. $\mathcal{F}$ Wood Chem Technol 11:159-169 (1991). 